\title{
Kondisi Kebisingan di Gedung Perkuliahan Universitas Bengkulu
}

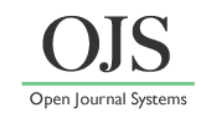

Abdul Rahman Singkam

Pendidikan Biologi, Fakultas Keguruan dan Ilmu Pendidikan, Universtas Bengkulu

Jl. W.R Supratman Kandang Limun Bengkulu 38371

Email: arsingkam@unib.ac.id

DOI: https://doi.org/10.33369/pendipa.4.2.14-20

\begin{abstract}
Learning activities require a conducive condition, including liberated of noise. This research aims to analyze the noisy level during learning activities in some lecture building of Universitas Bengkulu (UNIB). The data was collected through systematic purposive sampling and analyzed descriptively. The level of sound at UNIB lecture buildings (GKB) 1 until 5, I and $J$ buildings was measured every five minutes during the interval 08.01 - 08.30, 08.31-09.00, 10.01 - 10.30, 11.16 - 11.45 and 13.01 - 13.30 (local time) for a day sampling. The results show the sound intensity at UNIB lecture buildings ranges from 46.6 to $89.8 \mathrm{dBA}$, with most of the data (81\%) were categorized as noisy, and above the threshold for education environment. The noise level was significantly different between buildings $\left(X^{2}=78.50, d f=5, P<0.001\right)$ and between time interval $\left(X^{2}=79.09, d f=29, P<0.001\right)$. The lowest average of noise was in J building i.e. $58.85 \mathrm{dBA} \pm 1.30$, while the highest was in $G K B 5,68.15 \mathrm{dBA} \pm$ 0.87. Based on the time interval, the lowest average was at 13.01-13.30 i.e. 59.20 dBA \pm 1.45 , while the highest at 10.01-10.30, $71.58 \mathrm{dbA} \pm 1.86$. This noise level was parallelly correlated with the estimation number of students using the building $\left(F_{1,4}=43.87, p<0.001, R 2=0.92\right)$, which indicated the main source for these noises are student activities. A high level of noise at UNIB lecture buildings need to be treated. A long term of noise can affect physiology and psychology of the students and reduce the effectivity of learning.
\end{abstract}

Keywords: Noise, teaching building, Universitas Bengkulu.

[ABSTRAK] Kegiatan pembelajaran membutuhkan lingkungan yang kondusif, termasuk bebas dari intensitas suara yang terlalu tinggi (kebisingan). Penelitian ini bertujuan untuk menganalisis intensitas suara lingkungan selama proses belajar mengajar di berbagai gedung kuliah Universitas Bengkulu (UNIB). Metode penelitian yang digunakan adalah analisis deskriptif dengan teknik pengumpulan data secara systematic purposive sampling. Data intensitas suara pada gedung kuliah Gedung Kuliah Bersama (GKB) 1 sampai 5, gedung I dan J dicatat setiap selang lima menit pada interval waktu 08.01 - 08.30, 08.31 - 09.00, 10.01 - 10.30, 11.16 - 11.45 dan 13.01 - 13.30 WIB selama satu hari. Hasil penelitian menunjukkan intensitas suara di gedung perkuliahan UNIB berada pada kisaran 46.6 hingga 89.8 dBA, dengan sebagian besar data (81\%) berada pada kategori bising dan tidak memenuhi baku mutu suara untuk lingkungan pendidikan. Nilai kebisingan ini berbeda nyata antar gedung $(X 2=78.50, d f=5, P<0.001)$ dan antar waktu pengukuran $(X 2=79.09, d f=29, P<0.001)$. Rata-rata kebisingan terendah ditemukan di gedung $J$ yaitu $58.85 \mathrm{dBA} \pm 1.30$, sedangkan rata-rata tertinggi ditemukan di GKB 5 yaitu 68.15 dBA \pm 0.87. Berdasarkan waktu, rata-rata kebisingan terendah pada pukul 13.01-13.30 WIB yaitu 59.20 dBA \pm 1.45, sedangkan rata-rata tertinggi pada pukul 10.01-10.30 WIB yaitu $71.58 \mathrm{dbA} \pm 1.86 \mathrm{dBA}$. Nilai kebisingan ini berbanding lurus dengan estimasi jumlah mahasiswa pengguna gedung $\left(F_{1,4}=43.87, p<\right.$ 0.001, R2=0.92), menunjukkan bahwa sumber utama kebisingan ini adalah dari aktivitas mahasiswa. Kebisingan di gedung perkuliahan Universitas Bengkulu ini merupakan hal yang harus segera ditanggulangi karena kebisingan jangka panjang dapat menimbulkan gangguan fisiologis dan psikologis yang berhubungan dengan penurunan kefektifan pembelajaran.

Kata kunci: Kebisingan, gedung perkuliahan, Universitas Bengkulu. 


\section{PENDAHULUAN}

Salah satu sarana penentu dalam kesuksesan kegiatan belajar mengajar adalah kondisi ruang kelas. Ruang kelas yang nyaman akan berkolaborasi dengan suasana pembelajaran yang kondusif, karena peserta didik dapat lebih fokus tanpa terganggu dengan suasana sekitar (Ahmad $\mathrm{dkk}, 2017)$. Beberapa faktor utama yang terkait dengan kenyamanan ruangan, termasuk ruang kelas, adalah desain interior, temperatur, pencahayaan, dan intensitas suara (Justian, 2012; Gunawan \& Faisal, 2017). Tidak terpenuhinya satu atau beberapa faktor tersebut dapat menyebabkan kegiatan di dalam suatu ruangan menjadi tidak optimal (Buratti \& Ricciardi, 2009). Salah satu di antara faktor-faktor tersebut yang menjadi persoalan terbesar dalam kegiatan pembelajaran adalah intensitas suara yang terlalu tinggi (kebisingan) (Justian, 2012).

Kebisingan merupakan nilai bunyi yang terlalu tinggi dan tidak dikehendaki syaraf pendengaran. Keputusan Menteri Lingkungan Hidup (Men-LH, 1996) mendefinisikan bahwa kebisingan adalah bunyi yang tidak diinginkan dari usaha atau kegiatan, dalam tingkat dan waktu tertentu yang dapat menimbulkan gangguan kesehatan manusia dan kenyamanan lingkungan. Sedangkan World Health Organization (WHO) mendefenisikan kebisingan sebagai suara yang tidak diperlukan dan memiliki efek buruk pada kualitas kehidupan, kesehatan, dan kesejahteraan. Kebisingan mengandung unsur subyektifitas, tergantung bunyi diinginkan atau tidak secara psikologis oleh suatu individu (Handoko, 2010). Intensitas kebisingan, seperti halnya bunyi, diukur dengan satuan desibel ampere (dBA), yang menunjukkan besar arus energi persatuan luas. Nilai ambang batas kebisingan (NAB) atau baku tingkat kebisingan adalah batas maksimal tingkat kebisingan yang diperbolehkan dibuang ke lingkungan dari usaha atau kegiatan, sehingga tidak menimbulkan gangguan kesehatan manusia dan kenyamanan lingkungan.

Kebisingan memberi pengaruh negatif pada sistem tubuh baik secara fisiologis maupun psikologis. Dampak fisiologis kebisingan antara lain peningkatan tekanan darah, peningkatan nadi, gangguan pedengaran, dan kontraksi pembuluh darah perifer terutama pada tangan dan kaki (Kristiyanto dkk, 2014). Secara psikologis, kebisingan akan menurunkan kemampuan komunikasi, konsentrasi maupun performa kerja (Riyanto, 2010), rasa tidak nyaman, tidak konsentrasi, cepat marah dan stres (Kristiyanto, 2014). Beberapa contoh kebisingan yang ditemukan dalam lingkungan pendidikan adalah suara lalu lintas kendaraan, dengungan konstan sistem ventilasi, dan suara-suara keras lainnya yang dapat menurunkan tingkat konsentrasi belajar. Menurut Sundari (2007), kebisingan merupakan "polusi tak terlihat" yang menyebabkan efek fisik dan psikologis. Dampak kebisingan terhadap manusia tergantung pada lama, intensitas dan frekwensinya. Makin lama telinga kita mendengarkan kebisingan, makin buruk akibatnya bagi kita, termasuk diantaranya pendengaran yang makin kurang.

Penelitian ini bertujuan untuk menganalis tingkat intensitas suara saat kegiatan pembelajaran di beberapa gedung perkuliahan Universitas Bengkulu. Hasil analisis tingkat intensitas suara di gedung perkuliahan ini diharapkan dapat menjadi rujukan pengelolaan gedung dan kondisi perkuliahan di Universitas Bengkulu. Menurut Kep men-LH no 58 tahun 1996, ambang batas kebisingan untuk lingkungan pembelajaran adalah $55 \mathrm{dBA}$. Nilai ambang batas atau baku kebisingan adalah batas maksimal tingkat kebisingan yang diperbolehkan dibuang ke lingkungan dari suatu usaha atau kegiatan. Nilai di bawah ambang batas merupakan nilai yang tidak menimbulkan gangguan kesehatan manusia dan kenyamanan lingkungan.

\section{METODE PENELITIAN Waktu dan tempat}

Pengambilan data intensitas suara pada beberapa gedung kuliah Universitas Bengkulu dilakukan pada bulan Mei 2019. Rincian waktu pengambilan data adalah sebagai berikut: $06 \mathrm{Mei}$ di gedung kuliah bersama (GKB) III dan IV; 07 Mei di Gedung J; 09 Mei di GKB I; 12 Mei di GKB II; 14 Mei di GKB V; dan 17 Mei 2019 di Gedung I.

\section{Alat dan Bahan \\ Alat-alat yang digunakan dalam penelitian ini adalah sound-level meter, kamera, dan stopwatch. Sedangkan bahan yang digunakan adalah alat tulis berupa buku dan pena.}




\section{Prosedur penelitian}

Pengambilan data intensitas suara pada penelitian ini dilakukan dengan metode pengambilan sampel acak sistematis (systematic random sampling). Pengambilan sampel di masing-masing gedung dilakukan per lima menit pada interval waktu berikut 08.01 - 08.30, 08.3109.00, 10.01 - 10.30, 11.16 - 11.45 dan 13.01 13.30 WIB. Rentang waktu ini dipilih karena merupakan jam aktif perkuliahan, sehingga diharapkan kondisi gedung dalam suasana optimal untuk kegiatan pembelajaran. Pengumpulan data dilakukan dengan cara berjalan di koridor gedung kuliah pada interval waktu di atas. Setiap mendekati menit ke-5 pada waktu tersebut, contoh $08.05,08.10$ dan seterusnya, pengumpul data mengambil posisi terdekat dengan ruang kuliah (namun tetap di luar ruangan) yang sedang melangsungkan kegiatan pembelajaran. Data kebisingan kemudian (diusahakan) diambil tepat setiap interval lima menit menggunakan sound level meter kapasitas 30-130 dBA, dengan tingkat keakuratan hingga $\pm 1.5 \mathrm{~dB}$. Terdapat enam buah data yang dikumpulkan, contoh 08.05, 08.10, 08.15, 08.20, 08.25 dan 08.30 , pada setiap interval waktu 30 menit, dengan 30 (enam data dan lima periode) total data per gedung. Data hanya diambil untuk kelas yang sedang melakukan kegiatan pembelajaran.

\section{Analisis Data}

Data intensitas suara pada penelitian ini dianalisis secara deskriptif kuantitatif berupa nilai rata-rata dan standard error untuk setiap interval waktu dan setiap gedung perkuliahan. Nilai ini kemudian dibandingkan dengan nilai baku mutu Kep-Men LH no. 58 tahun 1996. Nilai rata-rata intensitas suara pada setiap gedung kemudian diregresikan dengan estimasi jumlah mahasiswa pengguna gedung. Pengguna gedung diestimasi dari data jumlah mahasiswa per fakultas di bagian registrasi Universitas Bengkulu.

\section{HASIL DAN PEMBAHASAN Hasil Pengamatan}

Hasil pengukuran intensitas suara di berbagai gedung perkuliahan Universitas Bengkulu menunjukkan kisaran angka antara 46.6 hingga $89.8 \mathrm{dBA}$, dengan nilai rata-rata $64.13 \mathrm{dBA}+0.71$ (Gambar 1). Sebagian besar data ini berada kategori bising dengan hanya 35 dari 180 data (19\%) yang berada di bawah baku mutu kebisingan lingkungan pembelajaran, di bawah 55 dBA (Kep-Men LH nomor 58 tahun 1996). 35 data intensitas suara yang berada di bawah baku mutu kebisingan ini secara berturut-turut adalah 11 data di gedung $\mathbf{J}$ (37\% dari total data gedung J), $9(30 \%)$ di masing-masing Gedung Kuliah Bersama (GKB) 2 dan Gedung I, 4 (13\%) di GKB 1, dan $2(6.7 \%)$ di GKB 3 dan 4. Tidak ada nilai intensitas suara yang berada di bawah baku mutu kebisingan untuk pembelajaran di GKB 5 . Berdasarkan waktu, 15 dari 35 (43\%) data tersebut berada pada pukul 13.01-13.30 WIB, 11 data (31\%) pada pukul 08.31-09.00, dan 4 data (11\%) masing-masing pada pukul 08.01-08.30 dan 11.16-11.45.

Nilai intensitas suara ini berbeda nyata antar gedung $(\mathrm{X} 2=78.50, \mathrm{df}=5, \mathrm{P}<0.001)$ dan juga berbeda nyata antar waktu pengukuran (X2=79.09, $\quad \mathrm{df}=29, \quad \mathrm{P}<0.001) . \quad$ Rata-rata kebisingan terendah ditemukan di gedung $\mathrm{J}$ yaitu $58.85 \mathrm{dBA} \pm$ 1.30. Sebaliknya, rata-rata kebisingan tertinggi ditemukan di gedung kuliah bersama (GKB) 5 yaitu $68.15 \mathrm{dBA} \pm 0.87$. Berdasarkan waktu, rata-rata kebisingan tertinggi pada pukul 10.01-10.30 WIB yaitu $71.58 \mathrm{dBA} \pm$ 1.86, sedangkan rata-rata kebisingan terendah pada pukul 13.01-13.30 WIB yaitu 59.20 dBA \pm 1.45 .

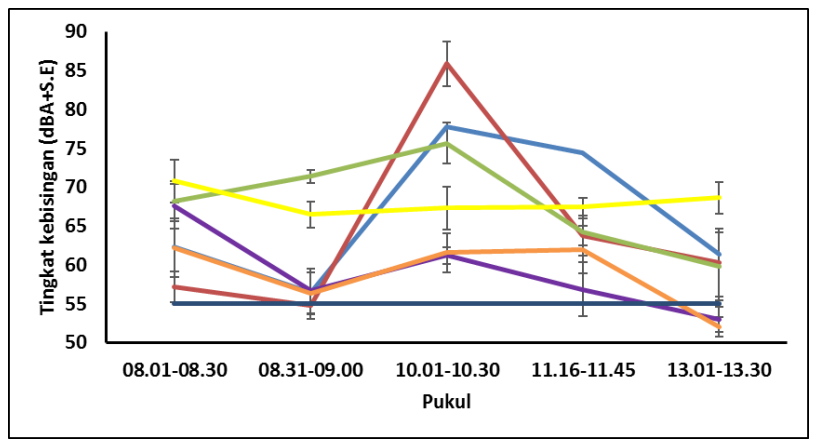

Gambar 1. Tingkat kebisingan di gedung kuliah Universitas Bengkulu (dBA+S.E), biru terang=gedung kuliah bersama (GKB 1), merah=GKB 2, hijau=GKB 3 dan 4 , kuning $=\mathrm{GKB} \quad 5$, ungu $=$ gedung $\mathrm{I}$, oranye $=$ gedung $\mathrm{J}$, biru tua $=$ standar kementerian lingkungan hidup 
Berdasarkan interval waktu yang disampling, waktu dengan kebisingan terendah adalah pada pukul 13.01-13.30 WIB dan 08.31-09.00. Meskipun demikian, sebagian besar sampel di interval 13.01-13.30 dan 08.31-09.00 (53\% dan $63 \%$ ) tetap berada pada kategori bising. Kebisingan paling tinggi ditemukan pada pukul 10.01-10.30 dengan hanya 1 dari 30 (3\%) sampel yang memenuhi baku mutu. Pengukuran pada periode 08.01-08.30 dan 11.16-11.45 menunjukkan hanya 4 dari $30(13 \%)$ sampel yang memenuhi baku mutu untuk lingkungan pendidikan.

Nilai kebisingan pada gedung kuliah Universitas Bengkulu berbanding lurus dengan perkiraan (estimasi) jumlah mahasiswa pengguna gedung. Kebisingan ditemukan lebih tinggi seiring dengan peningkatan jumlah mahasiswa pengguna gedung $\left(\mathrm{F}_{1,4}=43.87, \mathrm{p}<0.001\right.$, $\mathrm{R} 2=0.92$; Gambar 2). Dua data dengan nilai residual tertinggi (anomali) dari grafik hubungan pengguna gedung dan nilai kebisingan ini ditemukan pada GKB 3-4, dan GKB 5. Nilai kebisingan pada GKB 3-4 lebih rendah dibanding garis rata-rata (trendline), sebaliknya nilai kebisingan di GKB 5 lebih tinggi dibanding garis rata-rata. Estimasi pengguna gedung didasarkan pada data registrasi mahasiswa Universitas Bengkulu pada tahun 2017/2018 (Tabel 1).

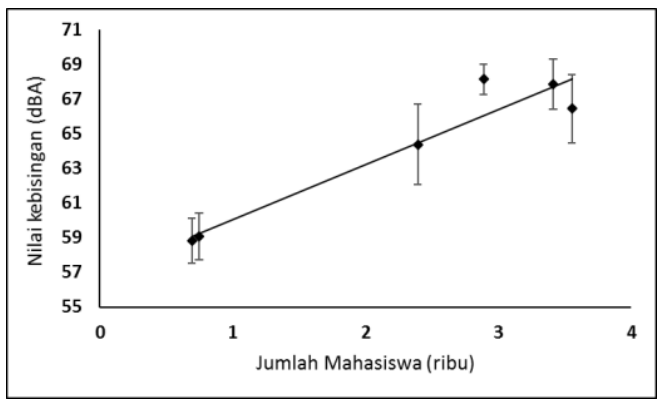

Gambar 2. Hubungan antara jumlah mahasiswa pengguna dengan tingkat kebisingan $(\mathrm{dBA}+\mathrm{S} . \mathrm{E})$ di beberapa gedung kuliah Universitas Bengkulu

\section{Pembahasan}

Hasil penelitian ini menunjukkan bahwa sebagian besar kondisi pembelajaran di gedung kuliah Universitas Bengkulu tidak optimal dari segi intensitas suara. $81 \%$ sampel menunjukkan bahwa kondisi gedung perkuliahan terlalu bising untuk digunakan sebagai tempat pembelajaran. Surat Keputusan Menteri Lingkungan Hidup nomor 58 tahun 1996 menyatakan bahwa baku mutu tingkat kebisingan di lingkungan sekolah atau sejenisnya adalah $<55,0 \mathrm{dBA}$, dan hanya $19 \%$ data pada penelitian ini yang memenuhi baku mutu tersebut. $78 \%$ data yang diperoleh berada pada kisaran 55-80 dBA, yang merupakan kondisi standar pada kantor yang bising, lalu lintas jalanan, suara radio, dan kawasan pabrik. 3\% data lain berada pada level di atas $80 \mathrm{dBA}$ yang merupakan suara normal di kawasan stasiun, pelabuhan dan bandara.

Tabel 1. Estimasi jumlah mahasiswa pengguna gedung dan tingkat kebisingan pada gedung kuliah di Universitas Bengkulu

\begin{tabular}{|c|c|c|c|c|}
\hline $\begin{array}{l}\mathrm{N} \\
\mathrm{o}\end{array}$ & $\begin{array}{l}\text { Nama } \\
\text { Gedun } \\
\mathrm{g}\end{array}$ & $\begin{array}{l}\text { Fakultas } \\
\text { Penggun } \\
\text { a }\end{array}$ & $\begin{array}{l}\text { Jumlah } \\
\text { Mahasiswa } \\
*\end{array}$ & $\begin{array}{l}\text { Kebisinga } \\
\mathrm{n}(\mathrm{dBA}) \pm \\
\text { S.E }\end{array}$ \\
\hline 1 & GKB 1 & Faperta & 3553 & $\begin{array}{l}66.457 \pm \\
1.98\end{array}$ \\
\hline 2 & GKB 2 & FISIP & 2394 & $\begin{array}{l}64.397 \pm \\
2.34\end{array}$ \\
\hline 3 & $\begin{array}{l}\text { GKB } 3 \\
\text { dan } 4\end{array}$ & FKIP & 3413 & $\begin{array}{l}67.863 \pm \\
1.44\end{array}$ \\
\hline 4 & GKB 5 & $\begin{array}{l}\text { FMIPA } \\
\text { dan FT }\end{array}$ & 2888 & $\begin{array}{l}68.153 \pm \\
0.87\end{array}$ \\
\hline 5 & $\begin{array}{l}\text { Gedun } \\
\text { g I }\end{array}$ & $\mathrm{FH}$ & 748 & $\begin{array}{l}59.073 \pm \\
1.34\end{array}$ \\
\hline 6 & $\begin{array}{l}\text { Gedun } \\
\text { g J }\end{array}$ & $\mathrm{FE}$ & & $\begin{array}{l}58.85 \pm \\
1.30\end{array}$ \\
\hline \multicolumn{5}{|c|}{$\begin{array}{l}\text { *didasarkan pada data registrasi mahasiswa } \\
\text { Iniversitas Bengkulu tahun akademik 2017/2018 }\end{array}$} \\
\hline $\begin{array}{l}\mathrm{Ha} \\
\text { kel } \\
\text { Be } \\
\text { jun } \\
\text { ini } \\
\text { sur } \\
\text { kul } \\
\text { ma } \\
\text { yar } \\
\text { bol } \\
\text { ma } \\
\text { suc } \\
\text { leb } \\
\text { ber }\end{array}$ & $\begin{array}{l}\text { peneliti } \\
\text { ingan } \\
\text { kulu ber } \\
\text { h maha } \\
\text { ecara ti } \\
\text { er utam } \\
\text { h Unive } \\
\text { siswa p } \\
\text { di baw } \\
\text { jadi ha } \\
\text { n sedikit, } \\
\text { ideal ur } \\
\text { rendah } \\
\text { ibungan } \\
\text { pada kec }\end{array}$ & $\begin{array}{l}\text { n ini juga } \\
\text { di gedu } \\
\text { lubungan } \\
\text { iswa pen } \\
\text { lak langs } \\
\text { a kebisin } \\
\text { rsitas Be } \\
\text { ngguna } \\
\text { h baku r } \\
\text { ya karen } \\
\text { bukan ka } \\
\text { tuk pemb } \\
\text { pada GK } \\
\text { dengan } \\
\text { ua gedun }\end{array}$ & $\begin{array}{l}\text { nenunjukka1 } \\
\text { g kuliah } \\
\text { secara signif } \\
\text { guna gedun } \\
\text { ng menyat } \\
\text { an di kaw } \\
\text { gkulu adal } \\
\text { edung. Nila } \\
\text { utu pada b } \\
\text { jumlah mah } \\
\text { ena kondisi } \\
\text { lajaran. Keb } \\
3 \text { dan } 4 \text { k } \\
\text { aktu penga } \\
\text { ini diambil }\end{array}$ & $\begin{array}{l}\text { bahwa nilai } \\
\text { Universitas } \\
\text { kan dengan } \\
\text { Hubungan } \\
\text { kan bahwa } \\
\text { san gedung } \\
\text { h aktivitas } \\
\text { kebisingan } \\
\text { berapa data } \\
\text { asiswa yang } \\
\text { edung yang } \\
\text { singan yang } \\
\text { emungkinan } \\
\text { bilan data. } \\
\text { ada tanggal }\end{array}$ \\
\hline
\end{tabular}


Ramadhan di tahun 2019. Sebagian mahasiswa pengguna gedung sepertinya tidak melakukan perkuliahan di hari tersebut karena beberapa ruang kelas ditemukan kosong. Ramadhan dkk (2016) menyatakan bahwa jumlah mahasiswa yang banyak merupakan faktor utama penyebab kebisingan pada lingkungan pendidikan.

Berdasarkan pengamatan, penyebab utama kebisingan ini adalah aktivitas mahasiswa mengobrol dan bercengkerama di luar atau di dalam kelas saat tidak ada kegiatan perkuliahan. Tidak adanya aktivitas pembelajaran di saat jam aktif perkuliahan ini dapat terjadi karena keterlambatan memulai perkuliahan, kuliah yang berakhir lebih cepat, dan atau pembatalan kuliah tanpa pemberitahuan ke mahasiswa. Aktivitas utama penyebab kebisingan ini seharusnya dapat diminimalisir jika setiap perkuliahan berlangsung sesuai dengan jadwal yang telah ditetapkan. Jika ada pembatalan kuliah, pemberitahuan seyogianya dilakukan sebelum mahasiswa berangkat ke gedung perkuliahan.

Penyebab lain kebisingan di gedung perkuliahan Universitas Bengkulu adalah aktivitas di parkiran seperti lalu lintas kendaraan dan percakapan pengguna parkiran. Aktivitas di parkiran ini terutama berdampak pada peningkatan kebisingan di ruangan lantai dasar. Beberapa penelitian (Indrawati dkk, 2017; Wali, 2019) menunjukkan bahwa aktivitas parkiran di kawasan pendidikan dan ibadah dapat mencapai hingga 86 dBA. Penelitian Indrawati dkk (2017) di kawasan parkir Sekolah Menengah Atas (SMA) di Surabaya menunjukkan nilai kebisingan tertinggi sebesar 78 dBA. Sedangkan penelitian Wali (2019) di kawasan masjid Baiturrahman Banda Aceh menunjukkan aktivitas parkiran dapat menyebabkan tingkat kebisingan hingga $86 \mathrm{dBA}$. Letak parkiran yang terlalu dekat dengan ruang kuliah otomatis menyebabkan suara di parkiran terdengar hingga ke ruang kuliah. Hal ini juga menunjukkan bahwa belum ada desain gedung ruang kuliah di Universitas Bengkulu belum terbebas dari pengaruh kebisingan di luar gedung. Berdasarkan penyebab di atas, sumber utama kebisingan dalam penelitian ini lebih mengarah ke kategori bising interior. Secara umum, sumber kebisingan dapat dibagi dalam dua kelompok yaitu bising interior dan bising luar (outdoor) (Doelle, 2013). Bising interior adalah sumber kebisingan yang paling sering dibuat oleh suara manusia, alat-alat rumah tangga dan mesin-mesin gedung. Sedangkan bising luar berasal dari lalu lintas, industri, alat-alat mekanis di luar gedung, aktivitas pembangunan, dan lain-lain.

Penanggulangan bising interior yang paling efektif dan ekonomis adalah dengan mengurangi sumber penyebab kebisingan (Ayuningtyas, 2010). Jika faktor tersebut berupa alat dan konstruksi, maka dapat dilakukan dengan penambahan peredam getaran atau gesekan seperti karet, busa dan sejenisnya (Handoko, 2010). Terkait dengan penelitian ini, maka menerapkan jadwal kuliah yang disiplin (ketat) merupakan hal yang paling efektif untuk mengurangi kebisingan di gedung perkuliahan. Penerapan jadwal yang on time akan menegasikan aktivitas mahasiswa mengobrol dan bercengkerama di sekitar ruangan perkuliahan. Selain itu, pemasangan perangkat penyerap bunyi dapat juga diaplikasikan untuk meminimalisir nada pantul (Handoko, 2010). Beberapa bahan yang umum digunakan untuk penyerap bunyi ini adalah berbagai jenis karpet dan selaput busa.

Penanggulangan bising luar, termasuk untuk kebisingan di gedung kuliah Universitas Bengkulu, dapat dilakukan dengan cara antara lain: pemindahan lokasi parkiran, penerapan waktu berkala aktivitas parkiran, dan atau pembuatan penghalang (barrier). Pemindahan lokasi parkir akan menjauhkan sumber bunyi, sedangkan penerapan waktu berkala akan membuat intensitas bunyi akan berkurang saat kegiatan perkuliahan. Pembuatan penghalang akan memantulkan atau menyerap bunyi dari parkiran sehingga menurunkan intensitas suara yang sampai ke ruang perkuliahan. Beberapa penghalang yang umum digunakan untuk meminimalisir kebisingan luar adalah gundukan tanah, vegetasi, beton, dan struktur pemantul atau penyerap bunyi lainnya (Mashuri, 2007; Ayuningtyas, 2010; Handoko, 2010: Chimayati, 2017).

Penanggulangan kebisingan di gedung perkuliahan Universitas Bengkulu ini merupakan hal yang harus segera dilakukan. Kebisingan jangka panjang yang tidak segera diatasi dapat menimbulkan gangguan terhadap pendengaran, kesulitan berkomunikasi, menimbulkan stress, terganggunya psikologi dan konsentrasi proses belajar mengajar (Men-LH, 1996; Ayuningtyas, 2010; Woolner \& Hall, 2010; Tjan dkk, 2013). 
Menurut Menteri negara lingkungan hidup (1996), akibat psikologis kebisingan antara lain berupa kehilangan konsentrasi, rasa tidak nyaman hingga timbulnya stress. Sedangkan Woolner \& Hall (2010) menjelaskan bahwa efek negatif kebisingan secara langsung pada proses pembelajaran adalah berupa kejengkelan atau bingung, dan tidak fokus pada pembelajaran. Penelitian Ayuningtyas (2010) menemukan bahwa tingkat kebisingan yang dapat diterima manusia terhadap kesehatan tergantung berapa lama kebisingan tersebut dipaparkan. Kebisingan yang terlalu lama akan berdampak terhadap gangguan pendengaran, gangguan saat komunikasi, dan stress. Lebih lanjut, Tjan dkk (2013) menjelaskan ada beberapa gangguan yang diakibatkan oleh kebisingan yakni gangguan komunikasi, gangguan pendengaran, gangguan psikologis, dan gangguan fisiologis.

\section{KESIMPULAN}

Berdasarkan hasil penelitian dapat disimpulkan bahwa: 1). Sebagian besar (81\%) sampel kegiatan perkuliahan di Universitas Bengkulu berlangsung dalam suasana bising, dan tidak memenuhi standar minimal suara untuk lingkungan pendidikan; 2). Nilai kebisingan ini berbeda nyata antar gedung dan juga antar waktu pengukuran; dan 3). Sumber utama kebisingan ini berasal dari mahasiswa, terutama aktivitas mengobrol dan bercengkerama saat tidak ada kegiatan perkuliahan.

\section{UCAPAN TERIMA KASIH}

Terima kasih kepada mahasiswa/i Program Studi Pendidikan Biologi angkatan 2016 yang telah membantu mengumpulkan dat penelitian ini.

\section{DAFTAR PUSTAKA}

Ahmad F, Handayani ID, Nurweni S. 2017. Analisis tingkat kebisingan terhadap aktivitas belajar mengajar di Fakultas Teknik Universitas Semarang. Jurnal Pengembangan Rekayasa dan Teknologi 13 (2): 29-34.

Ayuningtyas D. 2010. Pengendalian bising lalu lintas di sekolah menengah studi kasus: SMPN 115 Jakarta dan SMAN 37 Jakarta. Universitas Indonesia: Skripsi

Buratti C, Ricciardi P. 2009. Adaptive analysis of thermal comfort in university classrooms: Correlation between experimental data and mathematical models. Building and Environment. 44 (4): 674-687.

Chimayati RL. 2017. Analisis tingkat kebisingan yang ditimbulkan oleh aktifitas bandar udara dan upaya pengelolaannya. Institut Teknologi Sepuluh Nopember: Skripsi.

Doelle LL. 2013. Akustik Lingkungan. Jakarta: Erlangga

Gunawan G, Ananda F. 2017. Aspek kenyamanan termal ruang belajar gedung sekolah menengah umum di wilayah Kec. Mandau. Jurnal Inovtek Polbeng 7 (2): 98103

Handoko JPS. 2010. Pengendalian kebisingan pada fasilitas pendidikan studi kasus gedung Sekolah Pasca Sarjana UGM Yogyakarta. Jurnal Sains dan Teknologi Lingkungan. 2 (1): 32-42.

Indrawati S, Santika BB, Suyatno. 2017. Analisis kebisingan arus lalu lintas terhadap kegiatan belajar mengajar (KBM) di SMA Swasta Surabaya. Jurnal Fisika dan aplikasinya 13 (1): 14-18.

Justian, A. 2012. Analisis pengaruh kebisingan terhadap performa siswa sekolah dasar di ruang kelas. Universitas Indonesia: Skripsi

Kristiyanto F, Kurniawan B, Wahyuni I. 2014. Hubungan intensitas kebisingan dengan gangguan psikologis pekerja departemen laundry bagian washing PT. X Semarang. Jurnal Kesehatan Masyarakat 2 (1): 75-79

Mashuri. 2007. Penggunaan akustika luarruangan dalam menanggulangi kebisingan pada bangunan. Jurnal SMARTek 5 (3): 196-206.

Menteri Negara Lingkungan Hidup [Men-LH]. 1996. Baku tingkat kebisingan; Surat Keputusan Menteri Negara lingkungan Hidup Nomor: Kep- 48/MENLH/1996/25 November 1996. Jakarta: Meneg LH

Ramadhan G, Sasmita A, Andrio D. 2016. Analisis kebisingan terhadap kegiatan perkuliahan di lingkungan Fakultas Teknik Universitas Riau. JOM F Teknik 3 (2): 1-7.

Riyanto H. 2010. Pengaruh kebisingan terhadap kelelahan pada tenaga kerja penggilingan padi di Kecamatan Karang Anyar. Universitas Sebelas Maret: Skripsi. 
Sundari ES. 2007. Studi untuk menentukan fungsi hutan kota dalam masalah lingkungan perkotaan. Jurnal PWK Unisba 6 (2): 68-83.

Tjan H, Lintong F, Supit W. 2013. Efek bising mesin elektronika terhadap gangguan fungsi pendengaran pada pekerja di Kecamatan Sario Kota Manado, Sulawesi Utara. Jurnal e-Biomedik 1 (1): 34-39.
Wali G.R. 2019. Kaji tingkat kebisingan pada area parkir roda empat di basement Masjid Raya Baiturrahman. Universitas Syiah Kuala: Skripsi.

Woolner P, Hall E. 2010. Noise in schools: A holistic approach to the issue. International Journal of Enviromnental Research and Public Health 7(8):3255-3269. 